\title{
Identification and Nutritional Evaluation of Potential Indigenous Browse Species in Guba Lafto District, North Wollo, Ethiopia
}

\author{
Mohammed $\mathrm{Ali}^{1}$, Kassahun Gurmessa ${ }^{2, *}$ and Ayantu Mekonnin ${ }^{2}$ \\ ${ }^{1}$ Bonga University, Bonga, Ethiopia \\ ${ }^{2}$ Wollega University, Nekemte, Ethiopia
}

*Corresponding author: Kassahun Gurmessa, Wollega University, Nekemte, Ethiopia, Tel: +2519218371; E-mail: Kassahun.hu@gmail.com

Received: 30 Mar, 2020 | Accepted: 12 Jul, 2020 | Published: 13 Aug, 2020

Citation: Ali M, Gurmessa K, Mekonnin A (2020) Identification and Nutritional Evaluation of Potential Indigenous Browse Species in Guba Lafto District, North Wollo, Ethiopia. J Anim Sci Res 4(3): dx.doi.org/10.16966/2576-6457.144

Copyright: (C) 2020 Ali M, et al. This is an open-access article distributed under the terms of the Creative Commons Attribution License, which permits unrestricted use, distribution, and reproduction in any medium, provided the original author and source are credited.

\begin{abstract}
The study was carried out in Guba lafto district, North Wollo zone of Amhara regional states of Ethiopia with the objective of identifying and nutritional evaluation of potential indigenous browse species. For the study the district was stratified in to three based on the altitude (low land, mid-high land and high land). Knowledgeable farmers of the three agro-ecologies were consulted to identify and describe major browse species of the areas. Foliage samples were collected and analyzed for their biomass yield and nutritional contents. Upon the study, 21 major browses were identified, of which 14 species were trees and 7 species were shrubs. Among identified species Acacia seyal, Acacia brevispica, Acacia asak, Oleaeuropea, Ziziphus mauritiana, Dodonia viscosa were the most dominant species of the district. The average nutrient composition of browse species was not significantly different among the three agro-ecologies $(p>0.05)$. But, there were significant differences among species of the same agro ecologies. Dodonia viscosa, Acacia asak, Grewia bicolor, Combretem molle, Dracentastewdneri, Ziziphus mourtiana, Cordia africana, Acacia previspica, Croton machrostachyus, Salix subserrata, Helichrysumcitrispinum, Croton dichgamus and Maesalanceolata) had a greater CP content than the average CP content $20.40 \%$ reported in present study. Ash value ranged from 5.2-12.63\%. Higher NDF content was observed in browses of low lands and mid-high lands (Grewia bicolor, $72 \%$ and Cordia africana $60.8 \%$ ) respectively. Generally higher crude protein, low Ash, low NDF, low ADF and low ADL content was observed from highland. Lower CP, high NDF, high ADF and high ADL content was recorded from low land and midhighland areas. The study result also indicated that the browse species identified could be used as protein supplement for dry seasons and therefore, detailed study on raising the species and further animal feeding experiment is required for better justification of their importance.
\end{abstract}

Keywords: Browse species; Guba lafto; Identification; Nutritional value; Indigenous

\section{Introduction}

In Ethiopia agriculture is the most important economic activity; accounting for about $50 \%$ of the Gross Domestic Product (GDP) of the country engaging more than $80 \%$ the population [1] and the sector generates $90 \%$ of export earnings [2]. Livestock which is an integral part of the agriculture contributes about $47 \%$ of agricultural economy [3]. This sub-sector adds significantly to the national food security and nutritional balance, provides raw materials such as milk and meat for the agro-processing industry, foreign exchange from the export of hides and skins, farm-yard manure, and draught oxen power for crop production.

Livestock in Ethiopia, as in many other parts of the world, is grazed on natural grass-based communal pastures, in land use systems that include forests, woodlands and swamps, and fallow lands. Many of the pasturelands located in these land use systems are declining in area because of conversion of land to crop agriculture and settlements [4-7]. Feeding of livestock in natural systems is therefore becoming a challenge and is partly limiting growth in the livestock sub-sector.
Seasonal availability of quality feed, high costs of supplementary concentrates and little knowledge about plantation of improved browse feed species also limits livestock productivity. The most contribution of browse species as animal feed is that it serves as a source of crude protein as well as ability of being green for longer time during the dry season $[6,8]$. Therefore, study on identification of indigenous browse plants feed types and their nutritive value, their spacial and temporal distribution is very important for sustainable feeding of livestock.

The first step in this direction is to generate information that will assist in making management decisions for pasture improvement leading to improved production from cattle. Such information includes knowledge of which species are currently exploited as fodder. Therefore, the present study was designed with the objective of identifying and evaluation of the nutritive value of potential indigenous Browse species of the district.

\section{Materials and Methods}




\section{Description of the study area}

The Study was conducted in Guba lafto District, North Wollo zone of Amhara Regional state of Ethiopia. It is located at $9.11^{\circ}, 14.59^{\circ}$ North latitude and $36.31^{\circ}, 39.81^{\circ}$ East longitude and at distance of $520 \mathrm{~km}$ from Addis Ababa the capital city of Ethiopia. The District is bordered on the North Giddan District, North West by Meket district, North east by Kobbo district, South East by Habru district and in the West by Delanta and Wadila district. The district consists of 34 rural kebeles (The lowest administrative unit of Ethiopia) and 2 special urban administrative kebeles making a total of 36 kebeles.

Topography of the Woreda is made up of chain of mountains, hills, valleys and altitude ranging from 1379- 3809 meter above sea level (m.a.s.l), exposed for sever natural resource degradation mainly soil erosion and deforestation. Agriculture is predominant activity of livelihood characterized by both crop and livestock production [9].

\section{Data collection}

Selection of the study areas and sampling: Stratified random sampling was employed to select respondent households following kebeles (the smallest administrative unit of Ethiopia) and agro-ecology (highland, mid highland and low land) as unit of strata. For each agro ecology 2 kebeles were selected of which 30 households with a total of 240 were selected randomly. We used semi-structured interviews, guided questionnaires, and direct observations to collect the data on general household characteristics of the District. For the study and identification of indigenous browse plants three types of grazing land types; bushed grassland, at least two years fallowed grass land and river banks were included. Then we employed an ethno botanical approach to document traditional knowledge associated with identification and use of indigenous multipurpose browse species (IMBS) by the local community of the District $[6,10,11]$. Accordingly, those plants listed as important for livestock feed were considered for assessment of their distribution in different grazing sites and for chemical analysis. Nine plots, each $10 \mathrm{~m} \times 10 \mathrm{~m}$ and $50 \mathrm{~m}$ apart, arranged along a transect line was used to score the frequency of occurrence of the browse plants in each grazing site for each Kebele. The frequency of occurrence of each plant was determined by considering the number of plots in which it was recorded, as a percentage of the total plots in the respective grazing site. Foliage samples of the listed species were taken, then pressed by plant presser and preserved until sent for scientific identification at Addis Ababa University.

\section{Determination of chemical composition}

For chemical analysis fresh leaves and twigs of each browse species weighing about $300 \mathrm{~g}$ was collected and then oven-dried. The oven dried samples were ground in a Willey Mill to pass through $1 \mathrm{~mm}$ sieve for the determination of chemical composition. Feed samples were analyzed for DM and ash using the method of [12]. Nitrogen was determined using the micro Kjeldehl method. Crude Protein (CP) was calculated as $\mathrm{N} \times 6.25$. Neutral Detergent Fiber $(\mathrm{NDF})$, Acid Detergent Fiber (ADF) and Acid Detergent Lignin (ADL) Contents were analyzed according to Van Soest PJ [13].

\section{Data analysis}

The data were organized, summarized and analyzed using the SAS statistical package (SAS, 2001) [14]. For data involving frequencies, descriptive statistics were employed; whereas quantitative variables were analyzed using analysis of variance procedures and when the F-test showed significant differences, the Turkey test was used to separate group means.

\section{Results}

\section{Livestock and constraints}

The present study revealed three types of economic activities of the district. These were; Crop livestock production, only Livestock production and only crop production. Large number of surveyed households of the three agro-ecologies are engaged in crop livestock production which actually highest in highland areas, whereas, the largest livestock production was observed in lowland area (Figure 1). From participant observations and informal conversations we determined that cattle and other ruminant livestock are reared essentially, for economic reasons, i.e., to earn income from the sale of meat, dairy products, and hides and Skins, and the sale of live animals. Most of households keep oxen for their draught power. Livestock also feature highly in the cultural and social life of the Guba lafto district. Ruminant animals are killed during cultural rituals and local festivities such as weddings, and burials.

Major livestock production constraints are presented in figure 2. In the study district, livestock feed shortage was the major problem, especially in dry season. Among the constraints of livestock, feed shortage accounts about $61.7 \%$ in low land, 55\% mid-highland and $48.3 \%$ high land areas. The study showed that the problem of feed shortage is followed by water shortage, animal diseases and predators in the district.

\section{Identified indigenous multipurpose browse Species}

Identified browse species: The list of indigenous multipurpose indigenous browse species identified with their vernacular and scientific names are indicated in table 1 . Twenty one indigenous browse species were identified from the three agro-ecologies of the study

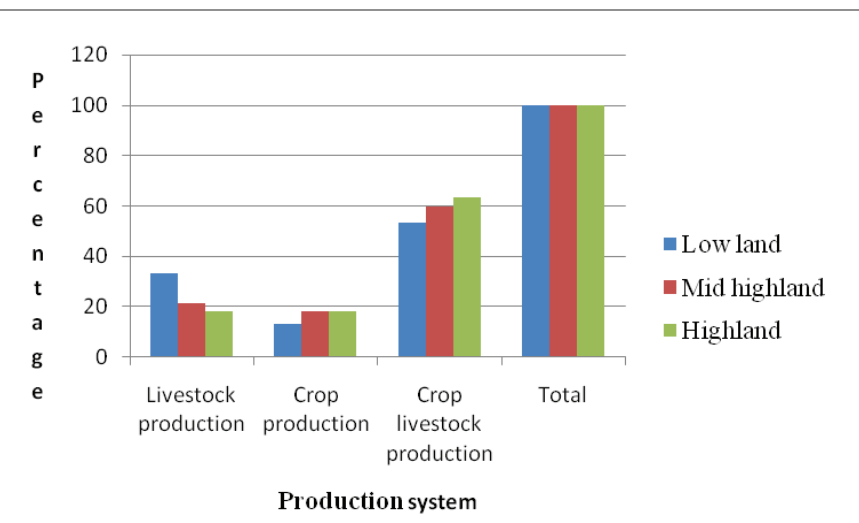

Figure 1: Economic activities of households of Guba lafto district.

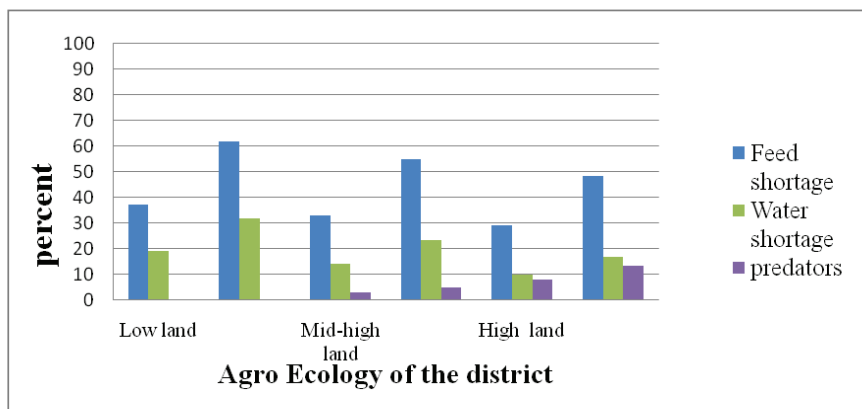

Figure 2: Constraints of livestock production in Guba lafto district. 
Table 1: Identified browse trees /bushes of the district.

\begin{tabular}{|c|c|c|c|c|c|}
\hline \multirow{2}{*}{ Scientific name } & \multirow{2}{*}{ Local name (Amharic) } & \multirow{2}{*}{ Family name } & \multicolumn{3}{|c|}{ Presence } \\
\hline & & & High land & Mid altitude & Low land \\
\hline Acacia seyal & Wacho & Fabaceae & & $\checkmark$ & $\checkmark$ \\
\hline Acacia asak & Seben & Fabaceae & & & $\checkmark$ \\
\hline Combretum molle & Aballo & Combretaceae & & & $\checkmark$ \\
\hline Oleaeuropea & Weira & Oleaceae & & & $\checkmark$ \\
\hline Dodoniaviscosa & Kitkita & Sapinadaceae & & $\checkmark$ & $\checkmark$ \\
\hline Carissa edulis & Agam & Apocynaceae & & $\checkmark$ & $\checkmark$ \\
\hline Ziziphusmauritiana & Kurkura & Rhomnaceae & & $\checkmark$ & $\checkmark$ \\
\hline Dracaena steudneri & Moata & Febaceae & & & $\checkmark$ \\
\hline Grewia bicolor & Sefa (Awrarisse) & Tiliaceae & & & $\checkmark$ \\
\hline Euclearacemosa & Dedeho & Ebenaceae & & & $\checkmark$ \\
\hline Allophylus abyssinicus & Tikur Embis & Sapindaceae & & & $\checkmark$ \\
\hline Cordia Africana & Wanza & Boraginaceae & & $\checkmark$ & \\
\hline Acacia brevispica & Kentafa & Fabaceae & & $\checkmark$ & \\
\hline Allophylus abyssinicus & Tikur Embis & Sapindaceae & & $\checkmark$ & \\
\hline Ehretiacymosa & Wulagga & Boraginaceae & & $\checkmark$ & \\
\hline Rhusglutinosa & AkakimaEmbis (Talembus) & Anacardiaceae & $\checkmark$ & $\checkmark$ & \\
\hline Hagenia abyssinica & Kosso & Rosaceae & $\checkmark$ & & \\
\hline Salix subserata & Ahaya(Rigga) & Salicoceae & $\checkmark$ & & \\
\hline Helichrysum citrispinum & Nechilo & Asteraceae & $\checkmark$ & & \\
\hline Croton dichogamus & Fiyelefeji & Euphorbiaceae & $\checkmark$ & & \\
\hline Croton macrostachyus & Bisana & Euphorbiaceae & $\checkmark$ & & \\
\hline Maesa lanceolata & Kelewo & Myrisinaceae & $\checkmark$ & & \\
\hline
\end{tabular}

$\checkmark$ =Show the presence of the plant

district of which eleven were found in lowland, nine in mid altitude and seven were identified in highland areas of the district. Most of browse plants identified from low land and mid-high land areas were shrub type while, more tree species were observed in the high land.

\section{Distribution of identified browse species across types of grazing lands}

The frequency of occurrence of each plant species in different agro ecologies and three types of grazing lands of the study areas are presented in tables 2-4. The result indicate that the distribution of each species vary according to the type of grazing land and agro ecology. In highland Helichrysum citrispinum is the most frequently observed species on grazing area (12 individual $\left./ 10 \mathrm{~m}^{2}\right)$ and the list recorded (1 plant $/ 10 \mathrm{~m}^{2}$ ) was Salix subserata from grazing land. On average ten Acacia seyal trees per $10 \mathrm{~m}^{2}$ were observed in grazing lands of low land areas and on average 9 Carissa edulisin per $\mathrm{m}^{2}$ were observed around river bank areas of mid altitude. However Salix subs errata was the least frequently found species (Table 2).

\section{Chemical composition of identified browse feed resources}

The average CP, Ash, NDF, ADF and ADL contents of identified indigenous browse species is presented in below tables 5-7. The comparison among the species found in each agro ecologies didn't have shown impressive $(\mathrm{P}>0.05)$ differences in nutrient but, the differences were significant $(\mathrm{P}<0.05)$ among the species.

The CP content of the browse species ranged from $7.6 \%$ in Euclearacemosa to 37.8 in Croton machrostachyus. The overall average fiber NDF, ADF and ADL contents of selected indigenous browse species in different agro ecologies is presented in tables 5-8. The average NDF, ADF and ADL contents of identified indigenous browse species were comparable $(\mathrm{P}>0.05)$ along agro-ecologies but, wider $(\mathrm{P}<0.05)$ differences were recorded among the species.

However numerical difference was observed in Euclea racemosa in low land. This could be due to higher temperature of low land and time of harvest of sample as it was taken at dry season.

\section{Discussion}

The present study revealed feed shortage, water shortage, disease and predators as the major constraints of livestock production in Guba Lafto District. Among these feed shortages is said to be the first constraint especially during dry season in all agro-ecologies of the study areas. Similar problems of livestock production was reported in different agro-ecologies of the country [4-7] and elsewhere in 
Table 2: Distribution of browse species in grazing land type of lowland $/ 10 \mathrm{~m}^{2}$.

\begin{tabular}{|l|c|c|c|c|}
\hline \multicolumn{1}{|c|}{ Browse species } & $\mathbf{R B} / \mathbf{1 0 \mathbf { m } ^ { 2 }}$ & $\mathbf{A H S} / \mathbf{1 0 \mathbf { m } ^ { 2 }}$ & $\mathbf{G A} / \mathbf{1 0 \mathbf { m } ^ { 2 }}$ & Total \\
\hline Acacia seyal & 2 & 2 & 4 & 8 \\
\hline Acacia asak & 2 & - & 3 & 5 \\
\hline Combretum molle & - & - & 3 & 3 \\
\hline Oleaeuropea & 1 & 2 & 2 & 5 \\
\hline Dodoniaviscosa & - & - & 4 & 4 \\
\hline Carissa edulis & 3 & - & 6 & 9 \\
\hline Ziziphusmauritiana & 1 & 3 & 3 & 7 \\
\hline Dracaena steudneri & - & - & 4 & 4 \\
\hline Grewia bicolor & - & - & 2 & 2 \\
\hline Euclearacemosa & 3 & - & 3 & 6 \\
\hline Allophylus abyssinicus & - & - & 2 & 2 \\
\hline RB
\end{tabular}

$\mathrm{RB}=$ River Banks; $\mathrm{AHS}=$ Around Home Stead; $\mathrm{GA}=$ Grazing Area; $\mathrm{m}^{2}=$ meter square

Table 3: Distribution of browse species in grazing land type of mid-high land $/ 10 \mathrm{~m}^{2}$.

\begin{tabular}{|l|c|c|c|c|}
\hline \multicolumn{1}{|c|}{ Browse species } & $\mathbf{R B} / \mathbf{1 0 m}^{\mathbf{2}}$ & $\mathbf{A H S} / \mathbf{1 0 m}^{\mathbf{2}}$ & $\mathbf{G A} / \mathbf{1 0 \mathbf { m } ^ { \mathbf { 2 } }}$ & Total \\
\hline Dodoniaviscosa & - & 2 & 4 & 6 \\
\hline Carissa edulis & 2 & - & 5 & 7 \\
\hline Ziziphusmauritiana & - & 3 & 3 & 6 \\
\hline Cordia Africana & - & 2 & - & 2 \\
\hline Acacia seyal & 3 & 2 & 3 & 8 \\
\hline Acacia brevispica & - & 2 & - & 2 \\
\hline Allophylus abyssinicus & 1 & - & 2 & 3 \\
\hline Ehretiacymosa & - & 3 & 1 & 4 \\
\hline Rhusglutinosa & - & 1 & 1 & 2 \\
\hline
\end{tabular}

$\mathrm{RB}=$ River Banks; $\mathrm{AHH}=$ Around Home Stead; $\mathrm{GA}=$ Grazing Area; $\mathrm{m}^{2}=$ meter square

Table 4: Distribution of browse species in grazing land type of highland $/ 10 \mathrm{~m}^{2}$.

\begin{tabular}{|l|c|c|c|c|}
\hline \multicolumn{1}{|c|}{ Browse species } & $\mathbf{R B} / \mathbf{1 0 m}^{\mathbf{2}}$ & $\mathbf{A H S} / \mathbf{1 0 m}^{\mathbf{2}}$ & $\mathbf{G A} / \mathbf{1 0 \mathbf { m } ^ { 2 }}$ & Total \\
\hline Hagenia abyssinica & - & 2 & - & 2 \\
\hline Salix subserata & - & - & 1 & 1 \\
\hline Rhusglutinosa & - & 1 & 3 & 4 \\
\hline Helichrysumcitrispinum & - & 5 & 7 & 12 \\
\hline Croton dichogamus & 2 & - & 6 & 8 \\
\hline Croton macrostachyus & 1 & 3 & 1 & 5 \\
\hline Maesalanceolata & - & 3 & - & 3 \\
\hline
\end{tabular}

$\mathrm{RB}=$ River Banks; $\mathrm{AHH}=$ Around Home Stead; $\mathrm{GA}=$ Grazing Area; $\mathrm{m}^{2}=$ meter square
Table 5: Chemical composition of browse plants in low land areas of Guba lafto district.

\begin{tabular}{|c|c|c|c|c|c|c|}
\hline Browse & $\begin{array}{l}\text { DM } \\
(\%)\end{array}$ & $\begin{array}{l}\text { Ash } \\
\text { (\%) }\end{array}$ & $\mathrm{CP}(\%)$ & NDF (\%) & $\begin{array}{l}\text { ADF } \\
\text { (\%) }\end{array}$ & $\begin{array}{l}\text { ADL } \\
(\%)\end{array}$ \\
\hline Allophylus abyssinicus & 94 & $7.44^{c}$ & $14.92^{h}$ & $40^{\text {de }}$ & $29.78^{f}$ & $6.66^{f}$ \\
\hline Dodoniaviscosa & 95 & $6.31^{\mathrm{ef}}$ & $19.15^{e}$ & $38.79^{e}$ & $27.36^{\mathrm{g}}$ & $5.71^{\mathrm{g}}$ \\
\hline Ziziphusmauritiana & 96 & $9.37^{\mathrm{a}}$ & $16.97^{g}$ & $35.55^{f}$ & $25^{\mathrm{j}}$ & $5.55^{\mathrm{h}}$ \\
\hline Eucleara & 96 & $6.25^{f}$ & $7.61^{k}$ & $56.31^{b}$ & $45.83^{b}$ & $11.23^{b}$ \\
\hline Acacia seyal & 95 & $7.36^{\mathrm{c}}$ & $27.3^{b}$ & $33.47^{g}$ & $23.15^{k}$ & $5.57^{\mathrm{h}}$ \\
\hline Carissa edulis & 95 & $8.42^{b}$ & $9.85^{i}$ & $56.72^{\mathrm{b}}$ & $44.21^{c}$ & $11.15^{b}$ \\
\hline Oleaes & 96 & $5.2^{\mathrm{g}}$ & $4^{j}$ & $41.46^{d}$ & $31.25^{\mathrm{e}}$ & $7.54^{\mathrm{d}}$ \\
\hline Acac & 94 & $6.38^{\text {de }}$ & 2 & sc & $36.17^{d}$ & $7.68^{c}$ \\
\hline Grewia bicolor & 93 & $6.45^{d}$ & $20.35^{d}$ & $72.47^{a}$ & $60.21^{a}$ & $17.58^{\mathrm{a}}$ \\
\hline Combretum molle & 95 & $6.31^{\mathrm{ef}}$ & $18.26^{f}$ & $35.36^{f}$ & $25.26^{i}$ & $5.71^{\mathrm{g}}$ \\
\hline Dracaena steudneri & 96 & $9.37^{a}$ & $24.19^{c}$ & $38.46^{\mathrm{e}}$ & $27.0^{\mathrm{h}}$ & $6.82^{\mathrm{e}}$ \\
\hline Mean & $\begin{array}{c}95 \pm \\
0.4\end{array}$ & $\begin{array}{l}7.17 \\
\pm 0.7\end{array}$ & $\begin{array}{l}17.78 \\
\pm 0.7\end{array}$ & $45 \pm 3.4$ & $\begin{array}{c}34.11 \\
\pm 3.1\end{array}$ & $\begin{array}{c}8.29 \pm \\
0.95\end{array}$ \\
\hline Significance & NS & $* * *$ & $* * *$ & $* * *$ & $* * *$ & $* * *$ \\
\hline
\end{tabular}

$\mathrm{DM}=$ Dry Matter; $\mathrm{CP}=$ Crud Protein; NDF=Neutral Detergent Fiber; $A D F=A c i d$ Detergent Fiber; ADL=Acid Detergent Lignin; \%=Percent; $* * *=$ significant at $\leq 0.001 ; \mathrm{NS}=$ Not Significant

Table 6: Chemical composition of browse plants in mid- high land areas of Guba lafto district.

\begin{tabular}{|c|c|c|c|c|c|c|}
\hline Browse species & DM (\%) & $\begin{array}{l}\text { Ash } \\
\text { (\%) }\end{array}$ & CP (\%) & $\begin{array}{l}\text { NDF } \\
\text { (\%) }\end{array}$ & $\begin{array}{l}\text { ADF } \\
(\%)\end{array}$ & $\begin{array}{l}\text { ADL } \\
(\%)\end{array}$ \\
\hline $\begin{array}{l}\text { A I I o } p h \text { h y I } \\
\text { abyssinicus }\end{array}$ & 96 & $11.45^{b}$ & $10.4^{\mathrm{g}}$ & $36.67^{e}$ & $25^{e}$ & $5.55^{e}$ \\
\hline Doc & 9 & & $3^{\mathrm{e}}$ & $31.24^{\mathrm{g}}$ & $2.91^{\mathrm{g}}$ & 500 \\
\hline Ziziphusmauritiana & 95 & $7.36^{c}$ & $28.55^{b}$ & $27.12^{\mathrm{h}}$ & $18.94^{i}$ & $3.41^{\mathrm{g}}$ \\
\hline Acac & $9 \Delta$ & $6.38^{\mathrm{d}}$ & $22.87^{c}$ & $40.36^{d}$ & $31.91^{\mathrm{d}}$ & $7.78^{d}$ \\
\hline Corc & 9 & $5^{a}$ & $.0^{\mathrm{a}}$ & $0.08^{\mathrm{a}}$ & $47.91^{\mathrm{a}}$ & $12.36^{a}$ \\
\hline Carissa edulis & 97 & $6.18^{e}$ & $8.75^{h}$ & $54.32^{\mathrm{b}}$ & $41.23^{b}$ & $10.31^{b}$ \\
\hline Rhusglutinosa & 97 & $6.18^{e}$ & $17.0^{\mathrm{e}}$ & $33.45^{f}$ & $22.68^{h}$ & $4.47^{f}$ \\
\hline Ehr & 95 & $12.63^{\mathrm{a}}$ & I & $31.27^{\mathrm{g}}$ & $3.15^{f}$ & $4.47^{f}$ \\
\hline Acacia brevispica & 94 & $7.44^{c}$ & $19.8^{d}$ & $52.24^{c}$ & $40.42^{c}$ & $8.92^{c}$ \\
\hline Mean & $\begin{array}{c}95.6 \pm \\
0.4\end{array}$ & \begin{tabular}{|c|}
$8.37 \pm$ \\
0.8
\end{tabular} & \begin{tabular}{c|}
19.06 \\
\pm 0.1 \\
\end{tabular} & $\begin{array}{c}40.75 \pm \\
0.02\end{array}$ & 30.46 & $\begin{array}{c}6.98 \pm \\
1.1 \\
\end{array}$ \\
\hline Significance & NS & $* * *$ & $* * *$ & $* * *$ & $* * *$ & $* * *$ \\
\hline
\end{tabular}

$\mathrm{DM}=$ Dry Matter; $\mathrm{CP}=$ Crud Protein; NDF=Neutral Detergent Fiber; $A D F=A c i d$ Detergent Fiber; ADL=Acid Detergent Lignin; \%=Percent, $* * *=$ significant at $\leq 0.001 ; \mathrm{NS}=$ Not Significant 
Table 7: Chemical composition of browse plants in high land areas of Guba lafto district.

\begin{tabular}{|l|c|c|c|c|c|c|}
\hline \multicolumn{1}{|c|}{ Browse species } & $\begin{array}{c}\text { DM } \\
\text { (\%) }\end{array}$ & $\begin{array}{c}\text { Ash } \\
\text { (\%) }\end{array}$ & CP (\%) & $\begin{array}{c}\text { NDF } \\
\text { (\%) }\end{array}$ & $\begin{array}{c}\text { ADF } \\
\text { (\%) }\end{array}$ & $\begin{array}{c}\text { ADL } \\
(\%)\end{array}$ \\
\hline Croton machrostachyus & 93 & $9.67^{\mathrm{b}}$ & $37.83^{\mathrm{a}}$ & $40.31^{\mathrm{b}}$ & $30.1^{\mathrm{b}}$ & $6.72^{\mathrm{b}}$ \\
\hline Salix subserata & 94 & $7.44^{\mathrm{d}}$ & $22.78^{\mathrm{e}}$ & $53.46^{\mathrm{a}}$ & $42.55^{\mathrm{a}}$ & $10^{\mathrm{a}}$ \\
\hline Helichrysumcitrispinum & 95 & $9.47^{\mathrm{c}}$ & $25.48^{\mathrm{d}}$ & $30.25^{\mathrm{d}}$ & $21.0^{\mathrm{de}}$ & $4.47^{\mathrm{c}}$ \\
\hline Hageniaabbyssinica & 91 & $5.49^{\mathrm{f}}$ & $17.37^{\mathrm{f}}$ & $35.41^{\mathrm{c}}$ & $24.17^{\text {cde }}$ & $5.57^{\mathrm{c}}$ \\
\hline Croton dichogamus & 91 & $5.49^{\mathrm{f}}$ & $29.1^{\mathrm{c}}$ & $29.73^{\mathrm{d}}$ & $19.78^{\mathrm{e}}$ & $3.41^{\mathrm{d}}$ \\
\hline Maesalanceolata & 93 & $11.82^{\mathrm{a}}$ & $33.89^{\mathrm{b}}$ & $38.57^{\mathrm{b}}$ & $27.95^{\mathrm{bcd}}$ & $5.47^{\mathrm{c}}$ \\
\hline Rhusglutinosa & 93 & $6.45^{\mathrm{e}}$ & $17.19^{\mathrm{g}}$ & $38.86^{\mathrm{b}}$ & $27.95^{\mathrm{bc}}$ & $5.46^{\mathrm{c}}$ \\
\hline Mean & $92.7 \pm$ & $7.98 \pm$ & 26.23 & 38.08 & $27.64 \pm$ & 5.87 \\
$\mathbf{0}$ & 0.9 & 0.6 & \pm 0.1 & \pm .4 & 0.9 & \pm 1.2 \\
\hline Significance & NS & $* * *$ & $* * *$ & $* * *$ & $* * *$ & $* * *$ \\
\hline
\end{tabular}

$\mathrm{DM}=$ Dry Matter; $\mathrm{CP}=$ Crud Protein; $\mathrm{NDF}=$ Neutral Deteregent Fiber; $A D F=A c i d$ Detergent Fiber; ADL=Acid Detergent Lignin; \%=Percent; $* * *=$ significant at $\mathrm{P} \leq 0.001$

Table 8: Average Chemical composition of browse species along altitude.

\begin{tabular}{|l|c|c|c|c|c|c|}
\hline \multicolumn{1}{|c|}{ Altitude } & $\begin{array}{c}\text { DM } \\
\text { (\%) }\end{array}$ & Ash (\%) & CP (\%) & NDF (\%) & AD F (\%) & ADL (\%) \\
\hline Lowland & $\begin{array}{c}95 \pm \\
0.4\end{array}$ & $\begin{array}{c}7.17 \pm \\
0.68\end{array}$ & $\begin{array}{c}17.78 \pm \\
0.7\end{array}$ & $45 \pm 3.4$ & $\begin{array}{c}34.11 \pm \\
3.1\end{array}$ & $\begin{array}{c}8.29 \pm \\
0.95\end{array}$ \\
\hline Mid-high & $\begin{array}{c}95.6 \pm \\
\text { land }\end{array}$ & $\begin{array}{c}8.37 \pm \\
0.76\end{array}$ & $\begin{array}{c}19.06 \pm \\
2.5\end{array}$ & $\begin{array}{c}40.75 \pm \\
3.7\end{array}$ & $\begin{array}{c}30.5 \pm \\
3.4\end{array}$ & $\begin{array}{c}6.98 \pm \\
1.1\end{array}$ \\
\hline Highland & $\begin{array}{c}92.7 \pm \\
0.9\end{array}$ & $\begin{array}{c}7.98 \pm \\
0.59\end{array}$ & $\begin{array}{c}26.23 \\
\pm .1\end{array}$ & $\begin{array}{c}38.08 \pm \\
04\end{array}$ & $\begin{array}{c}27.64 \pm \\
0.9\end{array}$ & $\begin{array}{c}5.87 \pm \\
1.2\end{array}$ \\
\hline Mean & 94.63 & 7.78 & 20.40 & 41.79 & 31.22 & 7.23 \\
\hline Significance & NS & NS & NS & NS & NS & NS \\
\hline
\end{tabular}

$\mathrm{DM}=$ Dry Matter; $\mathrm{CP}=$ Crud Protein; $\mathrm{NDF}=$ Neutral Detergent Fiber; $A D F=$ Acid Detergent Fiber; $A D L=A c i d$ Detergent Lignin; \%=Percent; NS=Not Significant

other countries [15] who reported that feed shortages and nutrient deficiencies as more acute in dry seasons. The study also revealed water shortage is the second most important constraints of livestock which more severely observed in lowland. Similar results were reported in the country [16]. Generally feed shortage was the major constraint of households in the district followed by water shortage, animal diseases and predators. This is in agreement with other studies [17-19] also reported that, the low veterinary service performance in the lowlands is the outcome of the government-monopolized services. Government veterinary staffs are few in number and cannot cover such a vast area to adequately address the veterinary needs. Besides government staffs need adequate mobile facilities for which currently the government does not have the capacity to provide [19]. Twenty one indigenous browse species were identified from the three agroecologies of the study district of which eleven were found in lowland, nine in mid altitude and seven were identified in highland areas of the district. Most of browse plants identified from low land and mid-high land areas were shrub type while, more tree species were observed in the high land. The fairly high number of bushes and shrubs types reported in low and mid altitude, indicates that the use of IMBS is more common and the reason for more browse species of animals are kept. This scenario agrees with reported studies in other similar areas of the country $[7,20]$. Among identified browse species, Acacia seyal, Acacia brevispica, Acacia asak, Oleaeuropea, Ziziphus mauritiana, Dodonia viscosa were dominant. With the agreement to this, similar species of browses were identified in other parts of the lowland areas of the country [21-24]. Overall, the respondents reported that it was becoming hard to find fodder for ruminants because of reductions in grazing areas. Farmers attributed the decline in pastoral area to several causes: conversion of communal grazing lands to agricultural use, shortening of fallow periods or absence of fallowing, short and erratic rainfall, and weed and other noxious plant invasion. The allocation of more land to crop agriculture to increase agricultural production and the shortening of fallow periods by farmers has made animal herding difficult, because animals stray into crop fields to feed fibrous crop residues. The average $\mathrm{CP}, \mathrm{Ash}, \mathrm{NDF}, \mathrm{ADF}$ and $\mathrm{ADL}$ contents of identified indigenous browse species didn't have showed impressive $(\mathrm{P}>0.05)$ differences but, the differences were significant $(\mathrm{P}<0.05)$ among the species. This could be resulted due to several factors which are said to be the basic contributors towards the variation in nutritive value of forages which include species, plant part and stage of maturity [25-27]. Other surveys on fodder trees also observed and reported this heterogeneity in nutrient composition in Ethiopia and elsewhere in other countries $[6,7,28]$. The CP content of the browse species ranged from $7.6 \%$ in Euclearacemosa to 37.8 in Croton machrostachyus. According to Topps JH, [29] Raj CU, et al., [30] and Kazemi M, et al. [31], feeds containing greater than $19 \% \mathrm{CP}$ are rated as having prime standard and those with CP values lower than $8 \%$ are considered to be of inferior quality. Browse species like Dodoniaviscosa, Acacia asak, Grewiabicolor, Combretem molle, Dracentastewdneri, Ziziphusmourtiana, Cordia africana, Acacia previspica, Croton machrostachyus, Salix subserrata, Helichrysumcitrispinum, Croton dichogamus and Maesalanceolata had a CP content greater than $18 \%$, suggesting the possibility of considering their use as an alternative plant protein sources to improve the nutritive values of poor quality feeds in the study area.

\section{Conclusion}

Livestock production is the major economic activity of Guba Lafto District. To counter the long term impact of declining feed resources in the country and study area in particular indigenous multipurpose browse plants with higher CP and lower fiber contents recorded in Guba Lafto district could be used to improve the fibrous less nutritious feed resources of dry season.

\section{Acknowledgement}

We deeply thank and acknowledge the people of Guba Lafto district who generously shared their knowledge. The authors gratefully acknowledge the Wollega University and Ministry of Education for funding the research budget. Holeta Agricultural Research Center of Ethiopia is also duly acknowledged for providing laboratory facilities for the study.

\section{References}

1. CSA (Central Statistical Agency) (2009) Federal Democratic Republic of Ethiopia, Agricultural Sample Survey. Addis Ababa, Ethiopia.

2. Samson, Frehiwot (2014) Spatial analysis of cattle and shoat population in Ethiopia: growth trend, distribution and market access.

3. Roy Behnke, Fitaweke Metaferia (2011) The Contribution of Livestock to the Ethiopian Economy Part II. IGAD Livestock Policy Initiative. 
4. Tolera A, Yami A, Alemu D (2012) Livestock feed resources in Ethiopia: Challenges, Opportunities and the need for transformation. Ethiopia Animal Feed Industry Association, Addis Ababa, Ethiopia.

5. Kassahun Gurmessa, Taye Tolemariam, Adugna Tolera, Fekadu Beyene (2016) Production and Utilization of Crop Residues in Horro and Guduru Districts, Western Ethiopia. Food Science and Quality Management 48.

6. Abebe M, Osting J, Fernandez-Rivera S, Van der Zijpp J (2008) Multipurpose fodder trees in the Ethiopian highlands: Farmers' preference and relationship of indigenous knowledge of feed value with laboratory indicators. Agric Syst 96: 184-194.

7. Kechero Yisehak, Geert PJ Janssens (2013) Evaluation of nutritive value of leaves of tropical tanniferous trees and shrubs. Livest Res Rural Dev 25.

8. Devendra C (1993) Trees and shrubs as sustainable feed resources. World conference on animal production, Edmonton, Canada 7: 119 138.

9. Wondimu B, Tewodros A (2006) The need potential constraints and research attempts of irrigation in Eastern Amhara. Amhara Region Agricultural Research Institute, Bahir Dar (Ethiopia) 16-25.

10. Paterson RT, Karanja GM, Roothaert RL, Nyaata OZ, Kariuki IW (1998) A review of tree fodder production and utilization within smal holder agroforestry systems in Kenya. Agrofor Syst 41: 181-199.

11. Roothaert RL, Franzel S (2001) Farmers preference and use of local fodder trees and shrubs in Kenya. Agrofor Syst 52: 239.

12. AOAC (1990) Official Methods of Analysis. $15^{\text {th }}$ Edition, Association of official analytical chemists, Arlington, VA, USA 1: 1298.

13. Van Soest PJ (1982) Nutritional ecology of ruminants. O and B books, Inc., Oregon, USA 374.

14. SAS (2001) STAT User's Guide Version 8.2. Statistical Analysis Systems Institute. Inc., Cary, NC, USA.

15. Tedonkeng PE, Pieper D (2000) Introduction to range Management in free and open access environments of Sub-Saharan Africa.

16. Ibrahim H, Olaloku E (2002) Improving cattle for milk, meat and traction. ILRI (International Livestock Research Institute), Nairobi, Kenya. ILRI, Manual 4: 135

17. Agajie Tesfaye, Chilot Yirga, Mengistu Alemayehu, Elias Zerfu, Aster Yohannes (2001) Small holder Livestock Production Systems and Constraints in the Highlands of North and West Shewa Zones. In: Proceedings of the $9^{\text {th }}$ Annual Conference of Ethiopian Society of Animal Production (ESAP) Held in Addis Ababa, Ethiopia 49-72.

18. Dereje T, Mengistu U, Getachew A, Yoseph M (2014) Perceptions of households on purpose of keeping, trait preference, and production constraints for selected goat types in Ethiopia. Trop Anim Health Prod 46: 363-370.
19. Alemayehu Seyoum Taffesse, Paul Dorosh, Sinafikeh Asrat (2011) Crop Production in Ethiopia: Regional Patterns and Trends. Development Strategy and Governance Division, International Food Policy Research Institute, Ethiopia Strategy Support Program II, Ethiopia ESSP II, Addis Ababa, Ethiopia.

20. Shenkute B, Hassen A, Assafa T, Amen N, Ebro A (2012) Identification and Nutritive Value of Potential Fodder Trees and Shrubs in the Mid Rift Valley of Ethiopia. The Journal of Animal \& Plant Sciences 22: 1126-1132.

21. Belayenesh D (2006) Florstic Composition and Diversity of the Vegetation, Soil seed bank Flora and Condition of the Rangelands of the Jijiga zone, Somali Regional State, Ethiopia. MSc Thesis, Presented to the School of Graduate Studies of Haramaya University 124.

22. Teferi A (2006) Identification and Nutritional Characterization of Major Browse species in Abergelle Woreda of Tigray. MSc Thesis Presented to the School of Graduate Studies of Haramaya University 75.

23. Ayana Angassa (1999) Range condition and traditional grazing management in Borana Ethiopia. MSc. Thesis, Presented to the School of Graduate Studies of Alemaya University, Alemaya, Ethiopia 73

24. Zinash S, Seyoum B (1989) Utilization of feed resources and feeding systems in the central zone of Ethiopia. Proceedings of the $3^{\text {rd }}$ National Livestock Improvement Conference, Addis Ababa, Ethiopia 129-132.

25. Solomon M (2001) Evaluation of selected multipurpose trees as feed supplements in teff (Eragrotis teff) straw based feeding of Menz sheep. Humboldt-University, Berlin 209.

26. Aster Abebe, Adugna Tolera, Øystein Holand, Tormod Ådnøy, Lars Olav Eik (2012) Seasonal Variation in Nutritive Value Of Some Browse and Grass Species In Borana Rangeland, Southern Ethiopia. Trop Subtro 15: 261-271

27. Brinkman WL, Leeuw PN (1976) The nutritive value of browse and its importance in traditional pastoralism. Mimeo, Agricultural Research Station, Shika, Ahmodou Bello University, Zaria, Nigeria.

28. Kaitho RJ, Tegegne A, Umunna NN, Nsahlai IV, Tamminga S, et al. (1998) Effect of Leucaena and Sesbania supplementation on body growth and scrotal circumference of Ethiopian highland sheep and goats fed teff straw basal diet. Lives Prod Sci 54: 173-181.

29. Topps JH (1997) Forage legumes as protein supplement to poor quality diets in the semi-arid tropics. FAO, UN.

30. Raj CU, Kumar BS (2006) Nutrient Contents of Feeds and Fodder in Nepal. Animal Nutrition Division, NARC Kathmandu, Nepal.

31. Kazemi M, Tahmasbi AM, Naserian AA, Valizadeh R, Moheghi MM (2012) Potential nutritive value of some forage species used as ruminants feed in Iran. Afr J Biotechnol 11: 12110-12117. 